\title{
Is There a Reserve Saving Effect of International Clearing Union? Testing for Asian Clearing Union
}

\author{
Vijay Singh Shekhawat*, Vinish Kathuria \\ Shailesh J. Mehta School of Management, Indian Institute of Technology Bombay, Mumbai, India \\ Email: *vsshekhawat@rbi.org.in
}

How to cite this paper: Shekhawat, V.S. and Kathuria, V. (2017) Is There a Reserve Saving Effect of International Clearing Union? Testing for Asian Clearing Union. Theoretical Economics Letters, 7, 562-574. https://doi.org/10.4236/tel.2017.73041

Received: March 1, 2017

Accepted: April 17, 2017

Published: April 20, 2017

Copyright ( $) 2017$ by authors and Scientific Research Publishing Inc. This work is licensed under the Creative Commons Attribution International License (CC BY 4.0).

http://creativecommons.org/licenses/by/4.0/ (c) (i) Open Access

\begin{abstract}
International Clearing Unions (ICU) are expected to save international reserves for their members. This study derives a benchmark for reserves saving (RSE) that includes all net reserve savings net of costs for inter-temporal credit that accrue from the clearing process within any ICU. As a test case, RSE of Asian Clearing Union (ACU) is computed and is found to be US $\$ 4.5$ billion per year over the period 2000 to 2015 . RSE ranges from zero to US $\$ 8$ billion. A counterfactual extension of ACU membership to Thailand and Malaysia indicates that the RSE may not necessarily increase. The RSE can be extended to any clearing system that follows the principles of inter-temporal credit, multilateral netting and uses single currency for netting and settlement. RSE of such a clearing systems will depend on the balance of credit and debit positions of members. RSE is highest when the trade is perfectly balanced and the countries follow a floating rate regime.
\end{abstract}

\section{Keywords}

International Clearing Union, Reserve Saving Effect, International Trade Settlements, Inter-Temporal Credit

\section{Introduction}

International Clearing Unions (ICU) ${ }^{1}$ are one of the instruments for economic integration and are expected to create conducive environment for increase in trade, to save foreign exchange reserves (henceforth, reserves) and pave the way for higher forms of economic integration [2] [3]. International trade is settled by payments in acceptable foreign currencies that are transmitted through corre-

${ }^{1}$ An ICU is a multilateral mechanism for periodic settlement of trade, on a net basis, through payments by central banks without relying on any particular country to supply the gross volume of currencies needed for such settlement [1]. 
spondent banks. ICU is an alternate mechanism whereby the trade payments are routed by the correspondent banks to a central bank or clearing agent. These central banks then hold the settlement receivable and payable positions for a pre-defined time period before netting them off. The netting is done on a multilateral basis by a central clearing agency. This mechanism is the core to functioning of an ICU. ICUs are expected to have a positive impact on the reserves of the countries and the magnitude of this impact is expected to depend on the balance of trade within the ICU [4]. A more balanced ICU will generate the highest possible reserve savings through a multi-lateral netting of trade receivables and payables. These savings are expected to reduce the demand for reserves, thereby providing stability to the exchange rates.

The economic impact of ICU is linked to this financial intermediation by an ICU, where it lends the savings of surplus countries to deficit countries during the process of multilateral netting [5]. Skidelsky [6] and Davidson [7] emphasize that ICU can shift the burden of balance of payment (BoP) adjustment on countries with surplus by automatically extending credit to debtors. Piffaretti [8] also supports the idea of a multilateral international clearing house that addresses the shortcomings of the national currencies reserve-based system by allowing adjustment through the debtors. Studies have also argued that ICUs would counter dampening effect on trade due to lack of reserves by putting the burden of adjustment on both surplus and debtor countries (see for example [1] [5] [6] among others). All these arguments assume that ICU would have large and significant effect on the foreign reserves of the members.

The interesting question that emerges is whether all ICUs necessarily generate large savings of reserves for all their members? Can such savings occur in absence of ICUs? Few studies have attempted to answer these question, even fewer have addressed the issue empirically and none have applied it to the oldest ICU, but still functional-the Asian Clearing Union (ACU). This paper uses a benchmark model for assessing the reserve saving effect (RSE) of an ICU and applies it to ACU as a case study. Results, using data from 2000 to 2015, indicate that members of an ICU have differential reserve savings. Positive RSE tends to have a direct relation with the size of the country's GDP and trade. Larger countries save more reserves while smaller countries have low or no savings of reserves. RSE can also occur without an ICU when countries have bilateral trade settlement arrangements. However, such RSE will be less than or equal to what can be generated by participating in an ICU. Counterfactual extension of ICU by expansion of membership indicates that inclusion of new members can enhance the RSE. The paper fills in the gap in literature by theoretical extension of a reserve saving effect model by included a term for cost of settlement, and its application for assessment of ACU in its existing form and its counterfactual extension.

The remaining paper is organised as follows. Section 2 explains the net settlement system of an ICU that leads to savings of reserves. Section 3 models the effects of ICU on the reserves as a measure of its effectiveness. Section 4 applies 
the model for assessing the effects of ACU and presents the results and Section 5 concludes.

\section{Net Settlement System of an International Clearing Union (ICU)}

Structure of an ICU is analogous to prevailing national net clearing and settlement system, where financial institutions settle their daily inter-institutional claims arising out of financial or trading, netted over a specific time window [8]. The main difference between ICU and a national net clearing system is that an ICU functions at two layers of netting-one at the national level where every central bank has a net receipt or payment at the end of each day that allows it to record the net debit or credit; and two at the ICU level where, at the end of the settlement cycle, each country's debit and credits are set off and a net position is arrived at. The net debit or credit position results in outflow or inflow of foreign currency, than may affect the foreign exchange reserves. The central bank is required to absorb all foreign exchange flows into its reserves either by purchasing it against issue of domestic currency or against issue of special currency like $\mathrm{Ba}$ $c o r^{2}$ or ACU Monetary Unit. Alternately, the central bank may also sell foreign currency against purchase of its own currency or special currency.

ICU attempts to equalize the debits and credits similar to assets and liabilities, in a closed system. If net credits equal debits in the system, no foreign currency flows exit the clearing union, then each member has full control over the exchange rate. In a market based trade settlement, if there are $n$ banks then we need $[n(n-1)] / 2$ conduits to effect the settlement while in an ICU framework we only need $(n-1)$ conduits. For example, if there are 10 banks each in three countries or a total of 30 banks in the system. Under ICU we can have a maximum of only 29 (i.e. $30-1$ ) flows between the banks where 29 banks send and 1 bank receives the funds on a net basis. Under a market based settlement, there can be a maximum of 435 [ $(30 \times 29) / 2]$ flows. Such flows of foreign exchange will have an impact on the balance of trade of the countries. In order to illustrate, we show a typical transaction flow under ICU with the net position of each country at the end of the settlement cycle (Table 1). Suppose there are four countries $A, B, C$ and $D$ that have bilateral trade. Country $A$ imports from $B$ and exports to $C$ and $D$.

Assuming that countries do not participate in an ICU, then country A will receive its surplus of 7000 (row 5 column 1) and pay its deficit of 5000 (row 6 column 1). Similarly, B will receive 2000 and pay 11,000 (row 5 and 6 of column 2), C will receive 7000 and pay 0 (row 5 and 6 of column 3) and D will receive 4000 and pay 6000 (row 5 and 6 of column 4). Since the receipts and payments will not match, all of them will have to arrange for funds to pay off their imports

${ }^{2}$ Bancor is a supranational international currency, suggested by Keynes and Schumpeter [9] that would be used for settlement of international trade commitments between countries that are member of an ICU. Bancor was to have a fixed exchange rate and would be used as a unit of account to measure the trade balance between nations. Every good exported would add Bancor to a country's account while every good imported would subtract Bancor. 
Table 1. Illustration of bilateral net positions in an ICU.

\begin{tabular}{|c|c|c|c|c|c|c|}
\hline & \multirow{2}{*}{ Countries } & $A$ & $B$ & $C$ & $D$ & Net Trade* \\
\hline & & 1 & 2 & 3 & 4 & 5 \\
\hline 1 & $A$ & - & -5000 & +4000 & +3000 & +2000 \\
\hline 2 & $B$ & -5000 & - & +2000 & -6000 & -9000 \\
\hline 3 & C & +4000 & +2000 & - & +1000 & +7000 \\
\hline 4 & $D$ & +3000 & -6000 & +1000 & - & -2000 \\
\hline 5 & Surplus & +7000 & +2000 & +7000 & +4000 & $+20,000$ \\
\hline 6 & Deficits & -5000 & $-11,000$ & 0 & -6000 & $-22,000$ \\
\hline 7 & Net Positions & +2000 & -9000 & +7000 & -2000 & -2000 \\
\hline
\end{tabular}

Note: -ve value indicates country's import from other countries, +ve value means export to other countries. * Net trade refers to the difference between the amount payable for imports and receivable for exports by the respective countries.

or deficits amounting to 22,000 (row 6 column 5). Hence on an aggregate the volume of international assets needed by these four countries would be 22,000 units.

On the other hand, if they decide to participate in an ICU, they need to pay only their net positions at the end of the pre-defined period, which is 9000 for country $B$ (row 7 column 2) and 2000 for country $D$ (row 7 column 4) i.e. a total of 11,000. In summary, while a gross system requires 22,000 units of international assets, the ICU reduces this demand to half of that. Extending the example, if we assume that the countries in net credit position ( $A$ and $C$ ) allow debtors to run their deficits for the next period then even the net payment of 11,000 is not needed provided the debtors are able to export to creditors an equivalent amount.

The effect of netting on the BoP position of the countries can be understood using standard Hecksher-Ohlin and Krugman models of international trade. In terms of these models, the budget constraint ${ }^{3}$ of the economy is determined by the terms-of-trade $e^{4}$ as a downward-sloped line with slope equal to the ratio of prices (P) of $x$ to $y$ where $x$ is the exportable commodity and $y$ is the importable i.e. $\frac{P_{x}}{P_{y}}$ (Krugman and Obstfeld, 2009). If we assume that country $A$ imports $Q_{x}$ units of $x$ commodity at price $P_{x}$ from country $B$ and country $B$ imports commodity $Q_{y}$ units of $y$ from country $A$ at price $P_{y}$. If there is only one period within which the $x$ and $y$ are exchanged and payments are settled and there were no prior reserves, then neither country can import for the other as they possess no reserves. In other words, it is constrained by existing balance of trade. In order to enhance the trade, either country will need to allow import by the other against credit. This can be illustrated with a stylized BoP statements of three ICU countries $A, B$ and $C$ over two periods (Table 2).

${ }^{3}$ Under conditions of autarky, a budget constraint represents the limitation of consumption by individuals in a country.

${ }^{4}$ The ratio of an index of a country's export prices to an index of its import prices. 
Table 2. Illustration of Inter-temporal BoP adjustment in presence of ICU.

\begin{tabular}{|c|c|c|c|c|c|c|c|c|c|}
\hline & \multicolumn{9}{|c|}{ Period 1} \\
\hline & \multicolumn{3}{|c|}{ Country $A$} & \multicolumn{3}{|c|}{ Country $B$} & \multicolumn{3}{|c|}{ Country $C$} \\
\hline & Export & Import & Net & Export & Import & Net & Export & Import & Net \\
\hline Merchandise & 70 & 5 & 65 & 10 & 50 & -40 & 20 & 35 & -10 \\
\hline Services & 10 & 5 & 5 & 1 & 11 & -10 & 5 & 15 & -10 \\
\hline $\begin{array}{c}\text { Total Current } \\
\text { Account }\end{array}$ & 80 & 10 & 70 & 11 & 61 & -50 & 25 & 45 & -20 \\
\hline \multirow[t]{2}{*}{$\mathrm{BoP}^{*}$} & 80 & 10 & 70 & 11 & 61 & -50 & 25 & 45 & -20 \\
\hline & \multicolumn{9}{|c|}{ Period 2} \\
\hline Merchandise & 20 & 80 & -60 & 20 & 10 & 10 & 35 & 15 & 20 \\
\hline Services & 10 & 20 & -10 & 50 & 10 & 40 & 30 & 30 & 0 \\
\hline $\begin{array}{c}\text { Total Current } \\
\text { Account }\end{array}$ & 30 & 100 & -70 & 70 & 20 & 50 & 75 & 45 & 20 \\
\hline $\mathrm{BoP}^{\star}$ & 30 & 100 & -70 & 70 & 20 & 50 & 75 & 45 & 20 \\
\hline
\end{tabular}

Note: BoP is Balance of payment; Capital Account, Reserves and Error and Omissions are assumed to be zero.

Let us assume that country $A, B$ and $C$ are members of ICU. In period 1 , countries $B$ and $C$ owe a total of 70 units $(55+15)$ to country $A$ on a net basis. With the introduction of credit for one period, the constraint is relaxed as in the next period, as the countries are able to offset their positions. Countries $B$ and $C$ now have a net export of 70 units that settles their dues to Country $A$ from period 1 . The only obligation that remains to be settled at the end of period 2 is the interest $r$ levied on the deficit countries B and C by country $A$. Hence, the obligations in one period get netted off in the second period and the net pay off of the countries is therefore lower.

In a nutshell, an ICU will reduce the volume of international assets required, pressurizes the debtors to correct their deficits, as countries with persistent debit positions will be restricted to access inter-temporal credits or they have to raise resources at higher costs [10]. All these benefits of ICU hinge on its ability to conserve reserves and create a system where the creditors with surplus extend credit to the debtors. We now formalize the above illustration into a model for estimating the reserve saving of an ICU.

\section{Benchmarking the Reserve Savings of an International Clearing Union}

Reserve savings under ICU happen when members net off their multilateral receipts and payments. Suppose a country $i$ has $X$ amount of exports and $M$ amount of imports from country $j$. At the same time, country $j$, also has some exports and imports from country $i$. If we assume that ICU settles the same, the country with less amount payable at time $t$ will not be required to pay at all. In a two country model, the trade dues of each country will be given by $\left(X_{i}-M_{i}\right)$ or $\left(X_{j}-M_{j}\right)$. 
As exports of one country equals import of the other (i.e., $\left.M_{i}=X_{j}\right)$, then the savings of an ICU is simply $M$. In case, if $X>M$, then $M$ need not be paid for as $X$ sets off the dues. If $M>X$, then $X$ amount need not be paid for and only $M-X$ is payable. Hence minimum of $X$ or $M$ is the savings from an ICU.

$$
\min \left[\sum X_{i, j}, \sum M_{i j}\right]
$$

Countries with pegged exchange rate will absorb the savings into their reserves. However, countries with a managed exchange rate can decide the extent to which the imports will be paid from reserves. Therefore, only a fraction of the imports $(M)$ are paid using reserves $(R)$, termed as the import cover ratio (i.e. $\frac{M}{R}$ ) [11] [12]. This implies that imports are fraction of reserves and of this fraction, only a small part is used for payment of imports. Of the amount payable as per Equation (1), only this fraction will contribute to reserve savings and not the entire amount. Stock $(R)$ to flow $(M)$ ratio gives us a unit of time $t$ [13]. For instance the $M$ of 12 months is 4 billion and $R$ is 12 billion, then, then $R / M$ is 3 years or 36 months. If we assume that all $M$ is paid from $R$, then for every $R$, only $2 / 3^{\text {rd }}$ will remain while $1 / 3^{\text {rd }}$ goes into payments. As at any time $t$, the recording of stock $R$ includes payments for flow $M$ made till $t$, then the $R$ at time $t$ is $[R+M]$. The ratio will then be $\frac{R}{R+M}$. To obtain standard flow to stock ratio, we divide both numerator and denominator with $R$ and get a fraction of imports that affect reserves, which is given by:

$$
\alpha=\frac{1}{\left[\frac{M}{R}+1\right]}
$$

$\alpha$ also captures the extent to which reducing one unit value of net imports by routing through the clearing union will help the country to reduce its foreign exchange reserves. Auguste [10] using a similar derivation identifies the contemporaneous reserve saving effect (RSE) for all countries participating in an ICU. Adjusting Equation (1) with Equation (2), we obtain the same

$$
\mathrm{RSE}=\alpha \min \left[\sum X_{i, j}, \sum M_{i j}\right]
$$

Generalizing Equation (3) for $p$ countries in an ICU gives us:

$$
\mathrm{RSE}=\alpha\left[\min \left(\sum_{i=1}^{P} X_{i}, \sum_{i=1}^{P} M_{i}\right)\right]
$$

In case of $p$ countries, however there is a possibility of both bilateral and multilateral netting of payments. Effects of ICUs are necessarily multilateral, hence we have to deduct the bilateral effect for pair of each trade partner. The RSE for country $j$ while removing bilateral effects with $j$ will then be given by the following identity.

$$
\operatorname{RSE}^{j}=\alpha\left[\min \left(\sum_{i=1}^{P} X_{i t}^{j}, \sum_{i=1}^{P} M_{i t}^{j}\right)-\left(\sum_{i=1}^{P-1} \min \left[X_{i t}^{j}, M_{i t}^{j}\right]\right)\right]
$$

Adding time $t$ into Equation (5) gives a flow to the index for reserve saving for the ICU. We make one more deduction in Equation (5) of autonomous flows 
like aids, grants, interest, capital gains etc. denoted by $R V$, that may increase the reserves without any contribution from the ICU. Incorporating these into Equation (5), we can now calculate the RSE for a country $j$ time $t$ in an ICU with $p$ members would be:

$$
\operatorname{RSE}_{t}^{j}=\alpha_{t}\left[\min \left(\sum_{i=1}^{p-1} X_{i t}^{j}, \sum_{i=1}^{p-1} M_{i t}^{j}\right)-\left(\sum_{i=1}^{p-1} \min \left[X_{i t}^{j}, M_{i t}^{j}\right]\right)-R V_{t}^{j}\right]
$$

Standard reports of any ICU publish data derived from Equation. (4) as the benefits accruing to countries (See for example ACU, 2014 for data on ACU [14]). However, in absence of adjustments shown in Equation (6), these benefits may be overstated.

\subsection{Modelling the Credit Arrangement within ICU}

Multilateral credit is the key to ICUs as it allows each member continue trade by using intra-temporal trade. Cost and availability of this credit is expected to be used as a tool for correcting the BoP imbalances. As explained above, under ICU mechanism, the debtor or creditor position is maintained in the books of the ICU and at the end of settlement period (say 1 month), the net position (debits minus credits) is arrived at. It may happen that some countries would have net credit while other have a net debit position. Assuming that the country is a gross importer within ICU i.e. it imports from all other members, then its position would be in debit against each country. In such a scenario, the debtor country can be assumed to avail multilateral credit from all other members for a period of say 1 month. At the end of the period, the debtor has to repay the creditors and the cycle commences once again from zero. Let the cost $(c)$ of this credit for 1 month (i.e. 30/365year) be charged at an annual interest rate of $r \%$. This cost for country $j$ for a credit over time $t$ will then be

$$
c=\frac{r t}{365}\left(\sum_{i=1}^{p-1} M_{i t}^{j}\right)
$$

For every country where gross exports exceed the gross imports from all other members, the RSE will then be given by the following identity

$$
\operatorname{RSE}_{t}^{j}=\alpha_{t}\left[\min \left(\sum_{i=1}^{p-1} X_{i t}^{j}, \sum_{i=1}^{p-1} M_{i t}^{j}\right)-\left(\sum_{i=1}^{p-1} \min \left[X_{i t}^{j}, M_{i t}^{j}\right]\right)-R V_{t}^{j}\right]-c_{t}^{j}
$$

Addition of $c$ to the RSE causes the model to capture all the financing costs and benefits (other than administrative costs) that can be obtained by joining an ICU. In case a country is a net importer from other countries, it will pay $c$ as financing cost and vice versa. This model is an improvement over Auguste [10] that limited the RSE to trade settlement benefits only.

This credit creation under ICU is analogous to financial intermediation in foreign currency markets. The theories of financial intermediation justify it based on liquidity and on transformation of risk characteristics of assets [15]. Both justifications hinge on more efficient allocation of resources by the financial intermediary leading to lowering of transaction cost. Past studies have been inconclusive on the effects of intermediation in foreign exchange markets. For example, Levine [16] does not find any evidence to recommend the bank-based 
over the market based credit. Williamson [17] also does not find any evidence that financial intermediation leads to better allocation of resources than what the market can otherwise garner. In a recent study Philippon [18] highlighted the increase in transaction cost due to intermediation. The study shows that even though there are diverse systems for risk mitigation, commercial activities have been charged higher by intermediaries like banks without any real reduction in risk. Poghosyan [19] findings also support the view that in low income countries, financial intermediation costs have not been declining primarily due to low banking competition and weak institutional frameworks. This high financial intermediation costs are symptomatic of a number of systemic problems including diseconomies of scale due to market fragmentation, high operating costs inefficient institutional environment and institutional interference in financial market activity. The presence of ICU in the foreign exchange market can also create an institutional structure that may fragment the market, have higher operating costs and market regulation that may divert trade (Pan A. Yotopoulos, 1992).

The interesting question that emerges from the example is whether such inter-temporal credit extends the budget constraint or is such credit adding to the costs? In order to examine this issue in depth, we take the case of Asian Clearing Union (ACU) and examine the effect of credit on easing of budget constraint using RSE as the indicator.

\subsection{Asian Clearing Union (ACU) - A Case}

ACU was established in 1974 under aegis of erstwhile Economic and Social Commission for Asia and Far East primarily to address the issues of trade imbalance in South Asia (Jalan, 2003). The initial signatories to the ACU agreement were Iran, Sri Lanka, India, Bangladesh, Nepal and Pakistan. Myanmar (Burma) joined later in 1977, Bhutan in 2000 and Maldives in 2009. The agreement states the four key objectives for setting up ACU with an international clearing system at its core. These objectives were to provide a multilateral net settlement facility for current international transactions; conserve foreign exchange reserves through this settlement facility; promote monetary co-operation for expansion of trade and to provide for currency swap arrangement as a means of temporary credit facility [20] [21].

In order to use ACU as a test case for ICU, it should broadly conform to principles enunciated by Keynes [9]. One major exception is the international currency (Bancor) envisaged by Keynes for ICUs, that is not a part of ACU framework. However, ACU uses ACU monetary unit that is pegged to US Dollar or Euro (as per the preference of the participants) allowing the trade settlements in a single currency. Table 3 compares the ACU objectives with the ICU framework proposed by Keynes.

The comparison indicates that ACU does not materially differ from the original idea. If the ACU framework is similar to the conventional ICU, it can be assumed that it will serve as a means to ease the international budgetary constraint. The constraint can be eased by generating RSE. Assessment of RSE of 
Table 3. Comparison of objectives of ACU with those of Keynes ICU framework.

\begin{tabular}{|c|c|c|c|}
\hline & Characteristics & ACU Objectives & Keynes Framework of ICU \\
\hline 1 & Mechanism & $\begin{array}{l}\text { Facility for payments for current } \\
\text { international transactions among the } \\
\text { members on a multilateral net basis. }\end{array}$ & $\begin{array}{l}\text { Increase exports and imports among } \\
\text { members by conservation of foreign } \\
\text { exchange in intra-group transactions } \\
\text { until the settlement. }\end{array}$ \\
\hline 2 & Currency & $\begin{array}{l}\text { Use of participants' currencies in trade } \\
\text { settlements leading to savings in foreign } \\
\text { reserves. }\end{array}$ & $\begin{array}{l}\text { Use of Bancor for trade settlements. } \\
\text { Bancor was expected to be an } \\
\text { instrument of international currency } \\
\text { having general acceptability. }\end{array}$ \\
\hline 3 & $\begin{array}{c}\text { Future } \\
\text { scenario }\end{array}$ & $\begin{array}{l}\text { To promote monetary co-operation } \\
\text { among the participants and closer } \\
\text { relations among the banking systems in } \\
\text { their territories-to facilitate expansion } \\
\text { of trade and economic activity among } \\
\text { the countries of the ESCAP region. }\end{array}$ & $\begin{array}{l}\text { Framework expected to use ICU as } \\
\text { ground for regional economic } \\
\text { co-operation in general and for } \\
\text { monetary and financial co-operation } \\
\text { in particular. }\end{array}$ \\
\hline 4 & Flexibility & $\begin{array}{l}\text { To provide for currency swap } \\
\text { arrangement among the participants so } \\
\text { as to make Asian Monetary Units } \\
\text { available to them temporarily. }\end{array}$ & $\begin{array}{l}\text { A system is expected to possess an } \\
\text { internal stabilizing mechanism } \\
\text { whereby creditors would temporarily } \\
\text { provide credit to debtors subject of } \\
\text { corrective action being initiated by } \\
\text { the later. }\end{array}$ \\
\hline
\end{tabular}

Source: Authors' compilation

ACU using benchmark model derived at Equation (8) now can be carried using data for its member countries.

\subsection{Data}

Data for the various variables for RSE (Equation (8)) require standard inputs to obtain comparable outputs. For instance, the exports and imports are required to be consistently measured in value terms without any change in cost, freight, insurance. The Direction of Trade (DoT) dataset compiled by the International Monetary Fund (IMF) is used for obtaining data on trade (export and import). We use monthly data from 2000 to 2015 giving us 180 observation for Bangladesh, Nepal, India, Pakistan and Sri Lanka with covering 90 settlement cycles, as ACU settles every two months. These observations cover any reversals, credit extensions and other seasonal trade that may occur in the region. This period is also preferred as it covers periods of extreme volatility in financial and commercial markets during the 2008 financial crisis. The trade data is in current price and denominated in millions of US Dollar. Exports are reported as free on board (FOB) and imports are on cost-insurance-freight (CIF) basis. While imports on FOB basis would be superior as it would exclude transportation costs (already estimated in distance), ACU member nations do not report the FOB. Large gaps in times series for Iran and Myanmar prompts us to exclude them from our analysis. Similarly, Maldives has joined the ACU in January 2010, hence is not a part of the analysis. Bhutan has been excluded due to absence of trade data and the fact that Indian Rupee is still used extensively for trade settlements converting it into an implicit currency union rather than a trade union. 


\section{Results and Discussion}

Table 4 reports the select key economic indicators of the ACU member countries. The economic indicators show the diversity among ACU countries. India has a relatively large GDP, exports, imports and reserves as compared to all other members.

All countries are trade deficit as the imports exceed the imports (columns 3 and 4). India has the highest foreign exchange reserves in the group indicating its ability to be the single largest creditor (column 5). Average outstanding IMF loans and credits reflects vulnerability to external flows requiring these countries to borrow from IMF (column 6). India and Pakistan have the maximum average outstanding loans while Bhutan has not availed any such loans. The summary statistics indicate the need for all countries to conserve reserves. Perhaps that might have motivated their ACU membership too. Using the benchmark model in Equation (8), we estimate the Reserve saving effect (RSE) for the ACU members from 2000 to 2015. The interest costs $c$ as charged to the ACU members are adjusted in calculation. Results are presented in Table 5.

Table 5 indicates that the RSE has been positive for most countries except for Nepal in 2002 and 2015. In these two years, the interest costs for participating in the ICU was equal to the gross reserve savings. The RSE rises as intra-ACU trade rises as it is has an axiomatic linear relation. If the ratio of reserves to imports (Import cover ratio) rises due to disproportionate increase in reserves, then increase in intra-ACU trade leads to higher RSE. This is because with increase in $\mathrm{R} / \mathrm{M}$ due to disproportionate increase in $\mathrm{R}$ (i.e., a country has adopted an export driven strategy), the percentage of reserves utilized for payments of imports will decline and at some stage, the stock-flow relationship ceases to have interaction. The country wise results indicate that while some countries like India and Pakistan may have large RSE, there are countries with zero RSE as well. In other words, ICU membership may not ensure RSE to all the member countries.

An interesting question is whether the low RSE is due to the present set of countries or can be generalized for all ICUs? In other words, if there were other countries in ACU, would the RSE be different?

Table 4. Select economic indicators of ACU member from 2001 to 2015 (US\$ Million).

\begin{tabular}{ccccccc}
\hline Country & GDP & GDP Growth rate & Exports & Imports & $\begin{array}{c}\text { Foreign } \\
\text { Reserves }\end{array}$ & $\begin{array}{c}\text { Average IMF Credits \& Loans } \\
\text { Outstanding (Million SDRs) }\end{array}$ \\
\hline & $(1)$ & $(2)$ & $(3)$ & $(4)$ & $(5)$ & $(6)$ \\
Bangladesh & 66,140 & $10.3 \%$ & 8769 & 15,591 & 4714 & 376 \\
India & 997,458 & $14.1 \%$ & 126,689 & 188,019 & 165,977 & -43.47 \\
Nepal & 9642 & $11.1 \%$ & 806 & 2921 & 1893 & 31 \\
Pakistan & 121,513 & $15.3 \%$ & 15,414 & 25,049 & 9624 & -22.10 \\
Sri Lanka & 29,730 & $14.7 \%$ & 6553 & 9535 & 3114 & -17.07 \\
\hline
\end{tabular}

Source: IFS, World Bank Database and ACU Annual reports. 
Table 5. Reserve saving effect of ACU members from 2001 to 2015 (US\$ Million).

\begin{tabular}{ccccccc}
\hline Year & Bangladesh & Nepal & India & Pakistan & Sri Lanka & RSE \\
\hline 2001 & $1(0.02)$ & $3(0.09)$ & $328(0.11)$ & $63(0.40)$ & $10(0.14)$ & 404 \\
2002 & $2(0.02)$ & $0(0.00)$ & $197(0.07)$ & $66(0.54)$ & $9(0.15)$ & 274 \\
2003 & $1(0.01)$ & $1(0.02)$ & $207(0.08)$ & $102(1.44)$ & $18(0.30)$ & 329 \\
2004 & $1(0.01)$ & $2(0.03)$ & $244(0.08)$ & $125(1.38)$ & $21(0.27)$ & 393 \\
2005 & $1(0.01)$ & $1(0.02)$ & $1787(0.54)$ & $132(0.91)$ & $6(0.10)$ & 1927 \\
2006 & $1(0.06)$ & $1(0.11)$ & $4290(10.24)$ & $86(4.46)$ & $9(0.81)$ & 4386 \\
2007 & $1(0.06)$ & $21(2.01)$ & $6256(11.06)$ & $107(2)$ & $21(1.55)$ & 6405 \\
2008 & $1(0.08)$ & $35(3.12)$ & $6119(7.48)$ & $137(1.37)$ & $19(0.97)$ & 6312 \\
2009 & $1(0.07)$ & $22(1.57)$ & $6178(5.4)$ & $238(2.19)$ & $19(0.92)$ & 6459 \\
2010 & $3(0.17)$ & $23(1.56)$ & $6848(5.07)$ & $274(2.64)$ & $25(1.12)$ & 7174 \\
2011 & $4(0.2)$ & $6(0.36)$ & $4495(2.9)$ & $418(3.82)$ & $28(1.03)$ & 4951 \\
2012 & $4(0.12)$ & $8(0.42)$ & $5662(2.58)$ & $273(2.02)$ & $73(2.43)$ & 6019 \\
2013 & $6(0.17)$ & $3(0.14)$ & $7030(2.5)$ & $282(3.17)$ & $140(4.15)$ & 7462 \\
2014 & $3(0.07)$ & $2(0.06)$ & $8064(3.14)$ & $248(2.55)$ & $154(5.59)$ & 8471 \\
2015 & $5(0.07)$ & $0(0.00)$ & $6963(2.63)$ & $289(2.16)$ & $130(2.46)$ & 7388 \\
\hline
\end{tabular}

Notes: ${ }^{*}$ sudden increase is caused by inclusion of oil import figures. Figure in parenthesis is the percentage of reserve savings to total reserves. The average RSE of Column 6 is US\$ 4.5 billion.

\section{Counterfactual Extension of ACU}

Counterfactual extension of an ICU is an interesting way of testing whether presence of more members in the ICU would have altered this position of low RSE. Similar counterfactual exercises have been used to study the hypothetical effects of ICUs by Duggan [1] and Hirai [21]. We evaluate the RSE for ACU by adding few more countries from South East Asia-Thailand and Malaysia and then compare the results. The selection of these two countries is based on their similarities with existing members, so the basic structure of flows within the ICU does not get disturbed. For instance, like existing ACU members, these two countries have formed economic associations to enhance trade, which will make it easier to integrate with a payment union. These countries follow precautionary reserve accumulation policies like most of the ACU members. The potential RSE for Thailand and Malaysia, if they become members of ACU, over the period is given in Table 6.

\section{Conclusions}

Any net clearing system, whether domestic or international, is expected to reduce the demand for settlement money and to provide inter-temporal credit. The efficiency of the net clearing system is usually measured by its netting benefits alone. We improve the Auguste [10] model for estimating the reserve savings effect (RSE) of an ICU by including the costs of intermediation. The model can 
Table 6. RSE of ACU after inclusion of Malaysia and Thailand (US\$ Million).

\begin{tabular}{cccccc}
\hline Year & Thailand & Malaysia & RSE-ACU* & RSE-Extended & Increase (\%) \\
\hline 2001 & 64 & 4 & 404 & 472 & 17 \\
2002 & 40 & 1 & 274 & 315 & 15 \\
2003 & 34 & 0 & 329 & 363 & 10 \\
2004 & 10 & 4 & 393 & 407 & 4 \\
2005 & 32 & 11 & 1927 & 1970 & 2 \\
2006 & 43 & 19 & 4386 & 4448 & 1 \\
2007 & 42 & 8 & 6405 & 6455 & 1 \\
2008 & 69 & 16 & 6312 & 6397 & 1 \\
2009 & 75 & 1 & 6459 & 6535 & 1 \\
2010 & 106 & 4 & 7174 & 7284 & 2 \\
2011 & 99 & 3 & 4951 & 5053 & 2 \\
2012 & 117 & 3 & 6019 & 6139 & 2 \\
2013 & 96 & 0 & 7462 & 7558 & 1 \\
2014 & 62 & 0 & 8471 & 8533 & 1 \\
2015 & 57 & 0 & 7388 & 7445 & 1 \\
\hline
\end{tabular}

Notes: ${ }^{*}$ RSE of select ACU countries from Table 5 (column 6); RSE-Extended is summation of RSE of select ACU members, Thailand and Malaysia.

be applied to any clearing system as a benchmark as it provides the net savings effect. As a test case, the RSE benchmark model evaluates Asian Clearing Union over 15 year period from 2000 to 2015 to find that on an US\$ 4.5 billion per year is the extent of reserve saving. However, there is a wide variation in the RSE and generally countries with low GDP have RSE as low as zero while countries with higher GDP save more, though as a percentage of their existing reserves, it is less than $5 \%$ for all countries. Countries with larger trade will have larger savings and thereby be able to enhance trade without being limited by international budget constraints. A counterfactual extension of ACU membership to Thailand and Malaysia indicates that the RSE may increase for the participating member but the increase is RSE is not assured.

We can generalize these findings for any clearing system that follows the principles of inter-temporal credit, multilateral netting and use of single currency. The RSE of a clearing system will depend on the balance of credit and debit positions of members. RSE will be highest when trade is balanced and the countries follow a floating rate regime. Expansion of ICU can have a beneficial impact on the RSE depending again on the same premise of balance of credits and debits. Future works can include costs like country risk permia in to further adjust the costs that are deductible from reserve savings. The counterfactual extension can also be extended to cover all countries that are already a part of a regional arrangement. 


\section{References}

[1] Duggan, M.C. (2013) Taking Back Globalization: A China-United States Counterfactual Using Keynes's 1941 International Clearing Union. Review of Radical Political Economics, 45, 508-516. https://doi.org/10.1177/0486613412475191

[2] Yoshimasa, K. and Tinbergen, J. (1966) International Economic Integration, Economic Review. Hitotsubashi University, 17, 187-189.

[3] Alessandrini, P. and Fratianni, M. (2009) Resurrecting Keynes to Stabilize the International Monetary System. Open Economies Review, 20, 339-358. https://doi.org/10.1007/s11079-008-9106-4

[4] Randall, W.L. (2013) Keynes: The Return of the Master. Eastern Economic Journal, 39, 134-137. https://doi.org/10.1057/eej.2010.42

[5] Romar, C. (2012) For an International Clearing Union. Journal of Economic Studies, 39, 398-409. https://doi.org/10.1108/01443581211255611

[6] Skidelsky, R. (2011) The Relevance of Keynes. Cambridge Journal of Economics, 35, 1-12. https://doi.org/10.1093/cje/beq043

[7] Davidson, P. (2009) The Keynes Solution: The Path to Global Economic Prosperity. Palgrave Macmillan, London.

[8] Piffaretti, N.F. (2009) Reshaping the International Monetary Architecture Lessons from Keynes' Plan. World Bank Policy Research Working Paper No. 5034.

[9] Moggridge, D. (1980) John Maynard Keynes XXV Activities 1940-1944 Shaping the Post War World the Clearing Union. Macmillan Cambridge University Press, London.

[10] Auguste, B.G. (1997) The Economics of International Payments Unions and Clearing Houses: Theory and Measurement. Palgrave Macmillan, London.

[11] Terada-Hagiwara, A. (2005) Foreign Exchange Reserves, Exchange Rate Regimes, and Monetary Policy: Issues in Asia. Asian Development Review, 22, 1-34.

[12] Arize, A.C. and Malindretos, J. (2012) Foreign Exchange Reserves in Asia and Its Impact on Import Demand. International Journal of Economics and Finance, 4, 21 32. https://doi.org/10.5539/ijef.v4n3p21

[13] Currie, D. (1976) Some Criticisms of the Monetary Analysis of Balance of Payments Correction. The Economic Journal, 86, 508-522. https://doi.org/10.2307/2230796

[14] ACU (2014) Annual Report. ACU Annual Report 162. www.asianclearingunion.org/Publications/AnnualReport.aspx

[15] Scholtens, B. and Van Wensveen, D. (2000) A Critique on the Theory of Financial Intermediation. Journal of Banking \& Finance, 24, 1243-1251.

[16] Levine, R. (2002) Bank-Based or Market-Based Financial Systems: Which Is Better? Journal of Financial Intermediation, 11, 398-428.

[17] Williamson, S.D. (1986) Costly Monitoring, Financial Intermediation, and Equilibrium Credit Rationing. Journal of Monetary Economics, 18, 159-179.

[18] Philippon, T. (2015) Has the US Finance Industry Become Less Efficient? On the Theory and Measurement of Financial Intermediation. American Economic Review, 105, 1408-1438. https://doi.org/10.1257/aer.20120578

[19] Poghosyan, T. (2013) Financial Intermediation Costs in Low Income Countries: The Role of Regulatory, Institutional, and Macroeconomic Factors. Economic Systems, 37, 92-110.

[20] ACU (1974) Asian Clearing Union Agreement. www.asianclearingunion.com

[21] Hirai, T. (2013) International Design and the British Empire: Keynes on the Relief Problem. History of Economics Review, 57, 63-83. 
Submit or recommend next manuscript to SCIRP and we will provide best service for you:

Accepting pre-submission inquiries through Email, Facebook, LinkedIn, Twitter, etc. A wide selection of journals (inclusive of 9 subjects, more than 200 journals)

Providing 24-hour high-quality service

User-friendly online submission system

Fair and swift peer-review system

Efficient typesetting and proofreading procedure

Display of the result of downloads and visits, as well as the number of cited articles Maximum dissemination of your research work

Submit your manuscript at: http://papersubmission.scirp.org/

Or contact tel@scirp.org 